\title{
INTRODUKSI GEN Sitrat Sintase KE DALAM RUMPUT LAUT Kappaphycus alvarezii MENGGUNAKAN Agrobacterium tumefaciens
}

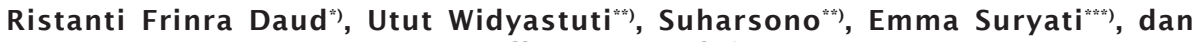 \\ Andi Parenrengi ${ }^{* * *}$ \\ *) Mahasiswa Program Stusi Bioteknologi SPs IPB \\ Kampus IPB Darmaga, Bogor \\ ${ }^{* *}$ Pusat Penelitian Sumberdaya Hayati dan Bioteknologi, IPB, dan Departemen Biologi, \\ FMIPA IPB \\ Kampus IPB Darmaga, Bogor \\ E-mail: Ututsuharsono2002@yahoo.com \\ ***) Balai Penelitian dan Pengembangan Budidaya Air Payau \\ Jl. Makmur Dg. Sitakka No. 129, Maros 90512 , Sulawesi Selatan
}

(Naskah diterima: 12 Juli 2013; Disetujui publikasi: 29 Juli 2013)

\begin{abstract}
ABSTRAK
Kappaphycus alvarezii merupakan salah satu rumput laut merah yang bernilai ekonomis penting. Ice-ice merupakan penyakit yang paling umum menyerang rumput laut dan menyebabkan menurunnya produksi rumput laut. Penyakit ini disebabkan oleh perubahan salinitas, suhu dan pencemaran logam berat. Asam sitrat digunakan sebagai pengkelat logam berat. Introduksi gen sitrat sintase ke dalam genom tanaman diketahui dapat mengurangi cekaman oksidatif. Penelitian ini bertujuan untuk mengintroduksi gen sitrat sintase ke dalam genom $K$. alvarezii menggunakan perantara Agrobacterium tumefaciens. Berdasarkan eksplan yang tahan pada media seleksi higromisin, efisiensi transformasi pada $K$. alvarezii sebesar 7,5\%. Efisiensi regenerasi tunas transgenik putatif sebesar 100\%, efisiensi tunas non transgenik sebesar 100\%. Analisis molekular menggunakan teknik PCR, satu dari lima K. alvarezii transgenik putatif mengandung transgen PaCS dibawah kendali promoter 35S CaMV.
\end{abstract}

KATA KUNCI: Kappaphycus alvarezii, rumput laut, gen PaCs, transformasi

ABSTRACT: Introduction of citrat syntase gene to Kappaphycus alvarezii using Agrobacterium tumefaciens. By: Ristanti Frinra Daud, Utut Widyastuti, Suharsono, Emma Suryati, and Andi Parenrengi

Kappaphycus alvarezii is one of the seaweed species that has high economical value. Ice-ice is an important disesase which can decrease the production of this seaweed. This disease can be caused by changes in salinity, ocean temperature, and heavy metals contamination. Citric acid has been used as chelating agent. Introduction of citrate synthase gene into plant had been reported to reduce oxidative stress. This research aimed to introduce citrate syntase gene into genome of $\boldsymbol{K}$. alvarezii mediated by Agrobacterium tumefaciens. Based on hygromicin resistant explant on hygromicin selection medium, the transformation efficiency in $\boldsymbol{K}$. alvarezzi was $7.5 \%$. The efficiency of shoot putative transgenic was $100 \%$, the 
efficiency of shoot non transgenic was 100\%. Molecular analysis by PCR showed that one of five putative $K$. alvarezzi transgenic was confirmed transgenic containing $\mathrm{PaCs}$ transgene under the control of $35 \mathrm{~S}$ promoter.

\section{KEYWORDS: Kappaphycus alvarezii, PaCs gene, seaweed, transformation}

\section{PENDAHULUAN}

Kappaphycus alvarezii (Doty) merupakan salah satu rumput laut merah yang bernilai ekonomis penting yang dinding selnya mengandung polisakarida tinggi, dan menjadi sumber penting karagenan di dunia (Bixler, 1996). Indonesia merupakan salah satu produsen rumput laut dengan rata-rata volume produksi 2.143.126 ton/tahun sejak tahun 2005 hingga 2010. Kebutuhan rumput laut dunia terus meningkat sekitar $27,63 \%$, namun dalam menghadapi pangsa pasar tersebut Indonesia belum mampu memanfaatkannya secara optimal (FAO, 2010).

Menurunnya kualitas rumput laut salah satunya disebabkan oleh penyakit ice-ice. Penyakit tersebut kemungkinan besar lebih banyak disebabkan oleh cekaman lingkungan daripada serangan patogen. Hal ini didukung dengan ditemukan fakta bahwa ice-ice lebih menonjol pada lingkungan yang kualitas airnya rendah, pergantian air sedikit, salinitas rendah dan perubahan suhu air serta kandungan logam berat yang tinggi di perairan (Mtolera et al., 1995). Logam berat yang banyak ditemukan di perairan adalah $\mathrm{Pb}, \mathrm{Mn}, \mathrm{Cu}, \mathrm{Cd}$ dan $\mathrm{Al}$ Jickells, 1955; De Baar \& La roche, 2003).

Cekaman logam berat berupa aluminium (Al) menyebabkan perubahan struktur sel yang meliputi reduksi jumlah butir pati dalam nukleoplas, inti sel tersegmentasi, dan adanya kondensasi kromosom pada inti (Nagy et al., 2004), serta kerusakan pada membran plasma. Cekaman Al mengakibatkan membran plasma kehilangan integritasnya (Yamamoto et al., 2001), yang selanjutnya memicu gangguan penyerapan hara dan air sehingga menyebabkan defesiensi unsur hara. Cekaman logam berat berupa timbal $(\mathrm{Pb})$ dan tembaga (Cu) pada Halophila ovalis menyebabkan aktivitas metabolisme terhambat sehingga berdampak pada ukuran daun mengecil (AmboRappe et al., 2011). Oleh karena itu, perlu dilakukan suatu upaya untuk meningkatkan ketahanan rumput laut terhadap cekaman logam berat yang salah satunya adalah dengan menigkatkan produksi asam sitrat rumput laut
K. alvarezii. Sitrat diketahui sebagai asam organik yang paling kuat dalam mengikat logam berat seperti aluminium. Asam sitrat dihasilkan dari siklus Kreb atau siklus asam sitrat. Siklus ini diawali dengan pengubahan pirufat menjadi asetil KoA dengan melepaskan $\mathrm{CO}_{2}$. Asetil KoA akan bereaksi dengan oksaloasetat yang berkarbon empat menjadi senyawa berkarbon enam sitrat. Enzim yang berperan dalam reaksi ini adalah sitrat sintase (Taiz \& Zeiger, 2002). Beberapa spesies dari genus Pseudomonas dimanfaatkan sebagai pelarut fosfat, yaitu dengan mensekresikan asam organik terutama sitrat (Buch et al., 2008). Gen sitrat sintase asal Pseudomonas aeuginosa ( $P a C s$ ) yang berukuran $1287 \mathrm{pb}$ dan menyandikan 428 asam amino telah berhasil diisolasi dan diintroduksikan kedalam tanaman Nicotiana tabacum dan Jatropha curcas melalui perantaraan Agrobacterium tumefaciens. Hasil uji tantang tembakau transgenik dengan cekaman Al menunjukkan bahwa tanaman transgenik yang mengandung gen $\mathrm{PaCs}$ lebih toleran dibandingkan dengan tanaman nontransgenik (Tistama, 2012).

Untuk meningkatkan dan mempertahankan produksi rumput laut nasional perlu dilakukan upaya-upaya dalam mengatasi permasalahan dalam budidaya, seperti menurunnya mutu genetik rumput laut akibat permasalahan penyakit dan lingkungan (Largo et al., 1997; Vairappan, 2006) melalui beberapa pendekatan teknologi, antara lain rekayasa genetik melalui transformasi genetik. Beberapa peneliti telah menggunakan $A$. tumeficiencens sebagai perantara transformasi, seperti yang dilakukan oleh Cheng et al. (2011) pada mikroalaga Schizochytrium. Pengembangan teknologi kultur jaringan merupakan salah satu teknologi yang mendukung rekayasa genetik pada tanaman. Teknik kultur jaringan rumput laut Kappaphycus alvarezii telah dikembangkan oleh Suryati \& Mulyaningrum (2009).

\section{BAHAN DAN METODE}

Penelitian ini dilakukan dari bulan September 2011 hingga Maret 2013, di Laboratorium Biotechnology Research Indonesia- 
Netherland (BIORIN) Pusat Penelitian Sumberdaya Hayati dan Bioteknologi (PPSHB), Institut Pertanian Bogor.

Rumput laut merah jenis $K$. alvarezii yang digunakan sebagai tanaman yang akan diintroduksikan diperoleh dari Laboratorium Balai Penelitian dan Pengembangan Budidaya Air Payau (BPPBAP) Maros. Bakteri $A$. tumeficiens LBA4404 yang membawa plasmid pMSH-PaCs digunakan untuk menginokulasi rumput laut $K$. alvarezii. Peta fisik daerah $\mathrm{T}$ DNA yang terdapat gen $\mathrm{PaCs}$ di bawah kendali promoter 35S CaMV disajikan pada Gambar 1. Primer spesifik PaCS-F (5'ATGGCTGACAAAAAAGCGCAG3'), PaCs-R (5'TCAGCCGCGATCCTTGAG GGC3'), dan 35SF (5'AAACCTCCTCGATTCC-ATT3') digunakan untuk mengetahui keberadaan gen $\mathrm{PaCs}$ di bawah kendali promoter 35S CaMV.

\section{Persiapan Eksplan}

Thalus $K$. alvarezii yang diperoleh dari Laboratorium Balai Penelitian dan Pengembangan Budidaya Air Payau (BPPBAP), Maros-Sulawesi Selatan digunakan sebagai eksplan. Thalus yang sehat dari penyakit dan bersih dari lumut dipotong sepanjang $5 \mathrm{~cm}$ dan dibersihkan dengan air laut yang disaring dengan filter UV. Thalus dibersihkan dengan sikat di bawah mikroskop, kemudian disterilisasi dengan betadin $1 \%$ di dalam air laut steril selama 1 menit, kemudian disterilisasi menggunakan campuran antibiotik (penisilin, kanamisin, streptomisin, ripamficin masing masing dengan konsentrasi 0,05\%) untuk menghilangkan mikroba permukaan. Untuk inisiasi dan penyesuaian pada kondisi laboratorium, thalus yang telah dipotong dikultur pada air laut steril yang diperkaya dengan provasoly enrichment seawater (PES) (116,88 g NaCl; $650 \mathrm{NaNO}_{3} 1 \mathrm{M} ; 3,2 \mu \mathrm{L} \mathrm{Na}$ glycerophospat $0,5 \mathrm{M} ; 76 \mu \mathrm{L} \mathrm{FeCl} \cdot 6 \mathrm{H}_{2} \mathrm{O}$ $0,01 \mathrm{M} ; 780 \mu \mathrm{L} \mathrm{Na}{ }_{2}$ EDTA $2 \mathrm{H}_{2} \mathrm{O} 0,01 \mathrm{M} ; 66 \mu \mathrm{L}$ Buffer Tris 0,01 M; 7,2 mL H3BO3; $14 \mu \mathrm{L} \mathrm{C}_{2} \mathrm{SO}_{4}$ 0,005 M; $60 \mu \mathrm{ZnSO}_{4} 7 \mathrm{H}_{2} \mathrm{O}$ 0,005 M; $8 \mu \mathrm{L}$ thia- $\min 1 \mathrm{mg} / \mathrm{mL} ; 0,8 \mu \mathrm{L}$ biotin $1 \mathrm{mg} / \mathrm{mL} ; 0,16 \mu \mathrm{L}$ B1 $210 \mathrm{mg} / \mathrm{mL} ; 1 \mathrm{~L}$ aqudest steril) dengan foto periode $12 \mathrm{jam}$.

\section{Kultur A. tumefaciens}

A. tumefaciens yang membawa gen $\mathrm{PaCs}$ dikultur dalam $3 \mathrm{~mL}$ media LB (20\% Bacto tryptone, $10 \%$ Bacto yeast, $20 \% \mathrm{NaCl}$ ) yang mengandung antibiotik $50 \mu \mathrm{g} / \mathrm{mL}$ streptomycin, $50 \mu \mathrm{g} / \mathrm{mL}$ kanamycin, $50 \mu \mathrm{g} / \mathrm{mL}$ higromisin dan diinkubasi dengan pengocok (shaker) dengan kecepatan $250 \mathrm{rpm}$, suhu $28^{\circ} \mathrm{C}$ selama 48 jam di ruang gelap. Setelah 48 jam biakan di subkultur lagi di dalam $20 \mathrm{~mL}$ LB selama 16 jam dengan kondisi yang sama. Selanjutnya kultur A. tumefaciens dimasukan ke dalam tabung masing-masing 1,5 $\mathrm{mL}$ disentrifugasi dengan kecepatan $4000 \mathrm{rpm}$ (Jouan centrifuge $B R$ 4i) selama 5 menit, kemudian endapannya diresuspensi dengan $20 \mathrm{~mL}$ media kokultivasi cair $(20 \mathrm{~mL} / \mathrm{L}$ PES; 20 part per thousand (ppt) air laut steril; $100 \mu \mathrm{M}$ asetosiringon; 0,05 g/ $100 \mathrm{~mL}$ glukosa) hingga nilai optical density $\left(\mathrm{OD}_{600}\right)$ 0,5.

\section{Transformasi genetik Kappaphycus alvarezii}

Prosedur transformasi pada rumput laut ini dilakukan dengan menggunakan thalus rumput laut yang dipotong-potong dengan ukuran $0,5 \mathrm{~cm}$ dan diadaptasikan terlebih dahulu pada media padat PES $0,8 \%(20 \mathrm{~mL} / \mathrm{L}$ PES; 30 ppt air laut steril; 0,8\% bacto agar) selama 3-5 hari. Transformasi dimulai dengan mencuci potongan thalus menggunakan air laut steril $30 \mathrm{ppt}$, kemudian dikeringkan pada tisu steril. Thalus yang telah dicuci, kemudian diinokulasi dengan cara direndam dalam biakan A. tumeficiens LBA4404 yang membawa plasmid pMSH-PaCs dalam media inokulasi (20 ppt air laut steril; $20 \mathrm{~mL} / \mathrm{L}$ PES; $100 \mu \mathrm{M}$ asetosiringon; $0,05 \mathrm{~g} / 100 \mathrm{~mL}$ glukosa) selama 15 menit. Thalus selanjutnya dikeringkan, pada tisu steril dan dipindahkan dalam media ko-kultivasi padat (25 ppt air laut; 0,3\% gelrite;

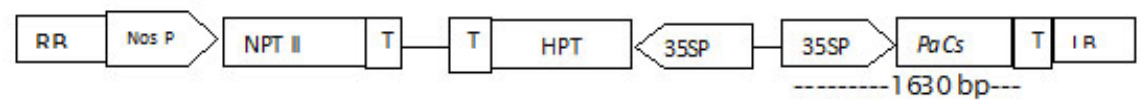

Gambar 1. Konstruksi gen PaCs di dalam vektor ekspresi pMSH (Tistama, 2012)

Figure 1. Construction of PaCS gene in PMSH expressing vector (Tistama, 2012) 
$100 \mu \mathrm{M}$ asetosiringon; $0,05 \mathrm{~g} / 100 \mathrm{~mL}$ glukosa) dan diinkubasi dalam ruangan gelap selama 23 hari. Selanjutnya thalus direndam di dalam air laut steril yang mengandung $200 \mathrm{mg} / \mathrm{L}$ cefotaxime selama 10 menit. Setelah itu thalus dibersihkan dan ditanam dalam media recovery (30 ppt air laut steril; $20 \mathrm{~mL} / \mathrm{L}$ PES; $0,4 \%$ bacto agar). Setelah 1-2 minggu, thalus dipindahkan ke media seleksi padat (air laut steril 30 ppt; PES $20 \mathrm{~mL} / \mathrm{L}$; bacto agar 0,5\%; higromisin $10 \mathrm{mg} / \mathrm{L}$ ). Setelah itu thalus tersebut kemudian di biakkan di media PES cair tanpa antibiotik (20 mL/L PES; 30 ppt air laut steril) diruang kultur jaringan hingga beregenerasi membentuk tunas.

\section{Analisis integrasi gen PaCs di dalam K. alvarezii}

Analisis integrasi gen $\mathrm{PaCs}$ di dalam genom K. alvarezii transgenik dilakukan dengan PCR. DNA genom diisolasi yang mengunakan teknik isolasi Joubert \& Fleurence (2005). Reaksi PCR dilakukan dengan mencampurkan 100 ng DNA genom, 0,5 mM kombinasi primer gen spesifik sitrat sintase PaCs-F dan PaCs-R, serta 0,5 mM kombinasi primer $35 s-\mathrm{F}$ dan PaCs-R, $5 \mu \mathrm{L}$ PCR mix, ditambah dengan $\mathrm{dd}_{2} \mathrm{O}$ hingga volume $10 \mu \mathrm{L}$. Kondisi PCR adalah denaturasi selama 30 detik pada suhu $95^{\circ} \mathrm{C}$, annealing selama 30 detik pada suhu $55^{\circ} \mathrm{C}$, dan ekstensi pada suhu $72^{\circ} \mathrm{C}$ selama 2 menit sebanyak 35 siklus. Sebanyak $5 \mathrm{~mL}$ hasil PCR dielektroforesis menggunakan gel agarose $1 \%$ dengan voltase 100 volt selama 30 menit dan selanjutnya gel direndam dalam etidium bromide $0,5 \mathrm{mg} \mathrm{L}^{-1}$ selama 20 menit, direndam 20 menit dengan air kemudian divisualisasi dengan UV transiluminator.

\section{HASIL DAN BAHASAN}

\section{Transformasi genetik Kappaphycus alvarezii dengan gen Sitrat sintase}

Introduksi gen $\mathrm{PaCs}$ ke dalam genom K.alvarezii dilakukan melalui perantara $A$. tumefaciens. Transformasi menggunakan $A$. tumefaciens memiliki beberapa kelebihan yaitu di antaranya mudah dilakukan (Hiei \& Komari, 2008). Kualitas eksplan yang digunakan dalam transformasi merupakan salah satu faktor yang menentukan keberhasilan transformasi. Eksplan yang digunakan pada penelitian ini adalah potongan thalus yang berwarna coklat tua dan tidak ada bagian eksplan yang mengalami perubahan warna setelah di tumbuhkan di media adaptasi. Thalus yang mengalami perubahan warna menjadi hijau tidak dapat digunakan dalam proses transformasi karena thalus tersebut tidak mampu beradaptasi dengan baik dan rentan terhadap kematian. Menurut Hiei \& Komari (2008), eksplan yang mendukung kesuksesan transformasi adalah eksplan yang segar dan sehat.

Transformasi dilakukan berdasarkan kemampuan A. tumefaciens mentransfer T-DNA kedalam kromosom tanaman. Transformasi genetik menggunakan $A$. tumefaciens telah dilakukan pada marine makroalaga yaitu Porphyra yezoensis (Cheney et al., 2011). Pada penelitian ini kokultivasi dilakukan dengan perendaman thalus pada suspensi $A$.
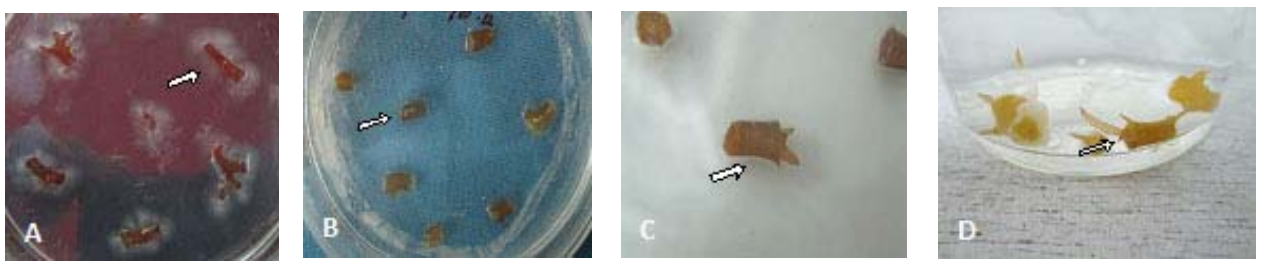

Gambar 2. Perkembangan transformasi rumput laut K. alvarezii menggunakan Agrobacterium tumefaciens pada $\mathrm{A}=$ media kokultivasi padat; $\mathrm{B}=$ media recovery; $\mathrm{C}=$ media seleksi mengandung higromisin $10 \mathrm{mg} / \mathrm{L}$; $\mathrm{D}=$ media aklimatisasi (PES cair) tanpa higromisin

Figure 2. Development of Agrobacterium tumefaciens transformed thalli Kappaphycus alvarezii on solid co-cultivation medium (A); recovery medium (B); selection medium containing $10 \mathrm{mg} / \mathrm{mL}$ hygromycin(C); $D=$ acclimatization medium (liquid PES) without hygromycin 
tumefaciens yang mengandung senyawa asetosiringon $100 \mu \mathrm{M}$ selama 10-15 menit yang selanjutnya dikeringkan kemudian ditanam pada media kokultivasi padat yang juga telah mengandung senyawa asetosiringon $100 \mu \mathrm{M}$ selama $2-3$ hari pada ruang gelap dengan suhu $25^{\circ} \mathrm{C}$ (Gambar 2$)$. Setelah dibiakkan di media kokultivasi, bakteri yang masih menempel pada thalus dibersihkan dengan perendaman di media yang mengandung cefotaxim. Cefotaxim ini berfungsi untuk membunuh $A$. tumefaciens tetapi tidak untuk rumput laut. Untuk melakukan regenerasi, thalus dipindahkan ke media recovery (Gambar 2). Konsentrasi cefotaxime yang digunakan pada penelitian ini lebih rendah daripada penggunaan konsentrasi cefotaxime pada penelitian tanaman tingkat tinggi. Konsentrasi cefotaxime yang efektif digunakan dalam mengurangi jumlah bakteri pada tanaman tingkat tinggi berkisar 250-1500 $\mathrm{gg} / \mathrm{mL}$ (Da silva \& Fukai, 2001). Pada konsentrasi yang tinggi, cefotaxime dapat merusak jaringan tanaman. Hasil penelitian Okkels \& Paderson (1988) menunjukkan bahwa cefotaxim dalam konsentrasi yang tinggi dapat bersifat phytotoxic pada perkembangan tanaman Bit. Pada dosis tertentu penggunaan cefotaxime pada proses transformasi tidak menghambat regenerasi tanaman (Koronfel, 1998).

Thalus yang mampu bertahan hidup pada media seleksi higromisin disebut thalus transgenik putatif. Pada penelitian ini, dari 200 eksplan yang diinokulasi dengan $A$. tumefaciens terdapat 15 thalus yang tahan terhadap higromisin sehingga efisiensi transformasi rumput laut berkisar 7,5\% (Tabel 1). Efisiensi transformasi ini lebih rendah jika dibandingkan dengan hasil penelitian Handayani (2013) yang memperoleh persentase transformasi pada $K$. alvarezii sebesar 23,56\%. Rendahnya persentase transformasi kemungkinan disebabkan oleh perbedaan genotipe $K$. alvarezii yang digunakan. Efisiensi regenerasi thalus transgenik putatif pada penelitian ini sebesar $100 \%$ dari jumlah eksplan yang resisten di media higromisin, sedangkan efisiensi regenerasi thalus non transgen sebesar 100\% di media non selektif yang tidak mengandung higromisin (Tabel 1). Efisiensi regenerasi pada penelitian ini lebih besar jika dibandingkan dengan efisiensi regenerasi pada hasil penelitian Handayani (2013) sebesar 11,32\%. Hal ini kemungkinan disebabkan penggunaan konsentrasi higromisin yang berbeda pada media seleksi dimana pada penelitian ini hanya menggunakan higromisin dengan konsentrasi $10 \mathrm{mg} / \mathrm{L}$ sedangkan pada penelitian Handayani (2013) menggunakan konsentrasi higromisin $20 \mathrm{mg} / \mathrm{L}$. Waktu yang diperlukan yang digunakan untuk regenerasi pada thalus transgenik lebih lama dibandingkan dengan thalus non transgenik. Hal ini kemungkinan disebabkan oleh beberapa faktor seperti

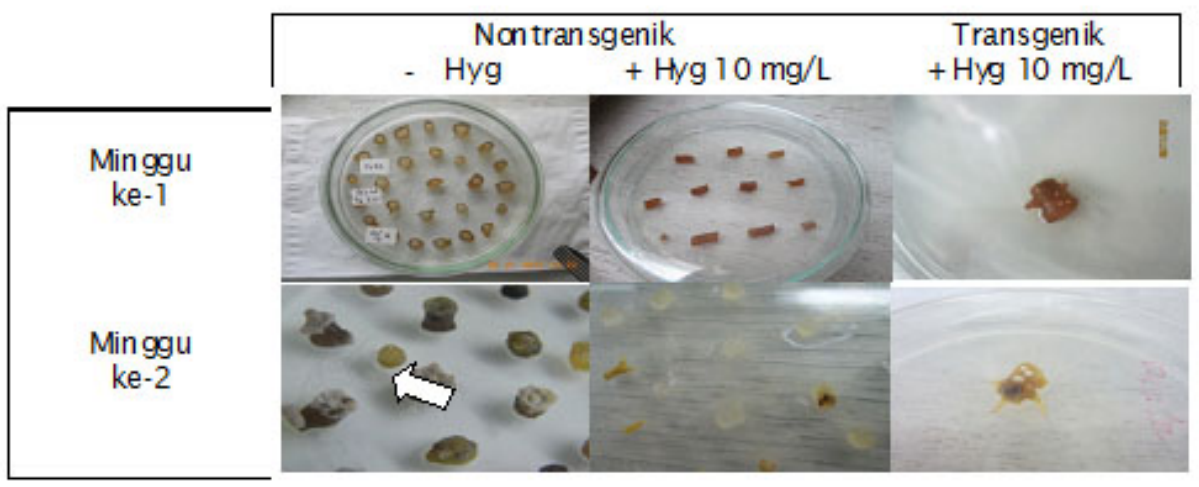

Gambar 3. Perkembangan eksplan nontransforman dan putatif transforman di media higromisin $10 \mathrm{mg} / \mathrm{L}(+\mathrm{Hyg})$ dan tanpa hygromisin (-Hyg)

Figure 3. Development of non-transformant explants and putative transformant explants on selection medium containing $10 \mathrm{mg} / \mathrm{L}$ hygromycin $(+\mathrm{Hyg})$ and without hygromycin (-Hyg) 
perlakuan infeksi $A$. tumefaciens dan pengaruh antibiotik higromisin. Dari 15 thalus transgenik putatif yang telah menghasilkan tunas, 3 thalus diambil secara acak untuk di analisis lebih lanjut. Jumlah tunas yang berhasil membawa gen $\mathrm{PaCs}$ yaitu 1 tunas dari 1 eksplan yang beregenerasi (Tabel 1). Perkembangan eksplan pada media selektif dapat dilihat pada Gambar 3.

Pertumbuhan thalus rumput laut $K$. alvarezii pada media PES non selektif yang tidak mengandung higromisin memperlihatkan pertumbuhan kristal filamen disekitar thalus (2 minggu), sedangkan thalus non transgenik yang ditanam pada media selektif menunjukkan hampir keseluruhan thalus mengalami kematian. thalus hasil transformasi yang ditanam pada media selektif menunjukkan pertumbuhan dimana tunas tumbuh semakin panjang (Gambar 3). Sensitivitas sel tanaman terhadap agen seleksi bergantung pada genotip, tipe eksplan, dan kondisi kultur jaringan (Koronfel, 1998).

\section{Analisis Integrasi gen PaCs di dalam K. alvarezii}

Dari 3 thalus yang menghasilkan tunas transgenik putatif, diambil 5 tunas untuk diisolasi DNA nya. Hasil isolasi DNA genom dari kelima tunas $K$. alvarezii transgenik putatif menunjukkan bahwa DNA tersebut memiliki kualitas yang baik (Gambar 4a). DNA genom dari salah satu tunas transgenik putatif selanjutnya digunakan untuk analisis integrasi gen $\mathrm{PaCs}$ pada K. alvarezii.

Analisis integrasi gen $\mathrm{PaCs}$ di dalam rumput laut menggunakan teknik PCR dengan primer gen $\mathrm{F} P a C s$ dan $\mathrm{R} P a C s$ menghasilkan pita berukuran $1300 \mathrm{pb}$, sedangkan pada $K$. alvarezii non transgenik tidak menghasilkan pita tersebut. Hal ini menunjukkan bahwa primer tersebut dapat digunakan untuk mengetahui keberadaan transgen $\mathrm{PaCs}$ di $\mathrm{K}$. alvarezii transgenik (Gambar 4b). Hasil ini juga menunjukkan bahwa rumput laut $K$. alvarezii mempunyai urutan nukleotida yang berbeda dengan gen PaCs dari Pseudomona aeruginosa. PCR dengan kombinasi primer 35s Fdan $\mathrm{R} \mathrm{PaCs}$ menghasilkan pita berukuran $1630 \mathrm{pb}$ pada $K$. alvarezii tetapi tidak menghasilkan amplikon pada K. alvarezii non transgenik (Gambar 4c). Hasil analisis ini menunjukkan bahwa gen $\mathrm{PaCs}$ pada $K$. alvarezii transgenik putatif dibawah kendali promoter 35S CaMV. Jadi, satu tunas $K$. alvarezii transgenik yang diambil secara acak dari 5 tunas yang telah diisolasi DNA nya adalah transgenik. Kombinasi primer ini juga digunakan untuk analisis integrasi gen $\mathrm{PaCs}$ pada Nicotiana tabacum dan Jatropha curcas (Tistama, 2012).

Tabel 1. Efisiensi transformasi dan regenerasi rumput laut Kappaphycus alvarezii mengandung gen Citrate syntase

Table 1. The efficiency of transformation and regeneration of Kappaphycus alvarezii containing Citrate syntase gene

\begin{tabular}{lcccccc}
\hline $\begin{array}{c}\text { Perlakuan" } \\
\text { Treatment }\end{array}$ & $\begin{array}{c}\text { Jumlah } \\
\text { eksplan aw al }\end{array}$ & $\begin{array}{c}\text { Jumlah eksplan } \\
\text { t ahan higromisin }\end{array}$ & $\begin{array}{c}\text { Persent ase } \\
\text { transform asi }\end{array}$ & $\begin{array}{c}\text { Jumlah eksplan } \\
\text { Regenerasi }\end{array}$ & Efisiensi PCR Regenerasi \\
\hline Diinokulasi & 200 & 15 & $7,5 \%^{\text {al }}$ & 15 & $1 / 1^{\text {*kok }}$ & $100 \%^{\text {b) }}$ \\
Tidak diinokulasi & 50 & 0 & 0 & 0 & 0 & 0 \\
Tidak diinokulasi & 50 & - & - & $50^{\text {*** }}$ & - & $100 \%^{{ }^{d}}$ \\
\hline
\end{tabular}

a) Jumlah eksplan tahan higromisin/jumlah eksplan $\times 100 \%$

b) Jumlah eksplan yang bertunas/jumlah eksplan tahan higromisin $\times 100 \%$

c) Jumlah eksplan yang bertunas/jumlah eksplan awal yang ditanam pada media tanpa higromisin $\times 100 \%$

*) Dengan $A$. tumefaciens

**) Di media yang tidak mengandung higromisin

***) Jumlah tunas dari 1 eksplan yang + PCR 
$4 \mathrm{a}$

$\lambda$ T1

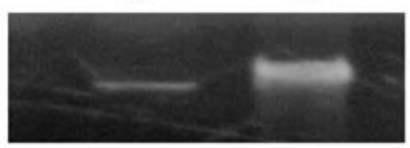

$4 \mathrm{~b}$

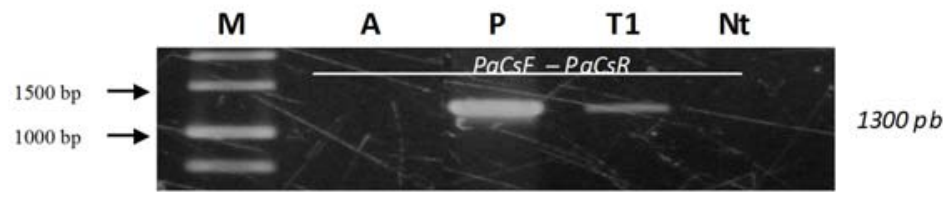

$4 \mathrm{c}$

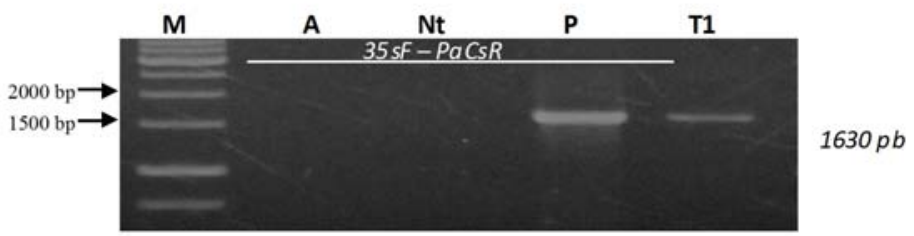

Gambar 4. Hasil elektroforesis DNA genom rumput laut Kapapphycus alvarezii (4a). Analisis integrasi gen PaCs di dalam thalus Kapapphycus alvarezii yang ditransformasi dengan Agrobacterium tumefaciens menggunakan PCR. $4 b=$ menggunakan kombinasi Primer F PaCs dan $\mathrm{R} \mathrm{PaCs}, 4 \mathrm{c}=$ menggunakan Primer $\mathrm{F} 35 \mathrm{~s}$ dan $\mathrm{R} P a C s$, Lajur $\mathrm{M}=$ Marker $1 \mathrm{~kb}, \mathrm{~A}=$ kontrol air, $\mathrm{P}=$ kontrol + plasmid, $\mathrm{T} 1=$ Rumput laut transgenik putatif, $\mathrm{Nt}=$ non transgenik

Figure 4. Electrophoresis of DNA genome Kapapphycus alvarezii (4a). Citrate syntase (PaCs) gene detection in Agrobacterium tumefaciens transformed thalli Kapapphycus alvarezii by PCR method. PCR product using F PaCs and R PaCs primers (4b); using $F 35 s$ dan $R$ PaCs primers (4c). M: 1 kb DNA marker; A:negative control (water); P:positive control (plasmid pMSH1-PaCs); T1: putative transgenic; Nt: non-transgenic

\section{KESIMPULAN}

Gen PaCs telah berhasil diintroduksikan dan terintegrasi di dalam genom rumput laut K. alvarezii dibawah kendali promoter $35 \mathrm{~S}$ CaMV.

\section{UCAPAN TERIMA KASIH}

Terima kasih diucapkan kepada penelitian kerjasama antara Balai Penelitian dan Pengembangan Kelautan dan Perikanan (BalitbangKP) Maros dengan Pusat Penelitian Sumberdaya Hayati dan Bioteknologi, Institut Pertanian Bogor (PPSHB_IPB) yang telah membiayai penelitian ini.

\section{DAFTAR ACUAN}

Ambo-Rappe, R., Lajus, D.L., \& Schreider, M.J. Heavy metal impact on growth and leaf asymmetry of seagrass, Halophila ovalis. J. Environ Chem Ecotoxicol,. 3(6): 149-159.

Buch, A.D., Archana, G., \& Naresh Kumar, G. 2008. Metabolic channeling of glucose towards gluconate in phosphate-solubilizing Pseudomonas aeruginosa p4 under phosporous deficiency. Res Microb., 159: 635-642.

Bixler, H.J. 1996. Recent developments in manufacturing and marketing carrageenan. Hydrobiologia, 326/327: 35-57. 
Cheng, R., Ruijuan, M.A., Ke Li , Hui, R., Xiangzhi, L., Zhaokai, W., Shanjun, Y., \& Yong, M. 2011. Agrobacterium tumefaciens mediated transformation of marine microalgae Schizochytrium. Micres., 25421: 1-8.

Cheney, D., Metz, B., \& Stiller, J. 2001. Agrobacterium-mediated genetic transformation

in the macroscopic marine red alga Porphyra yezoensis. J. Phycol., 37: 11-13.

Da Silva, J.A. \& Fukasi, S. 2001. The impact of carbenicillin, cefotaxime and vancomycin on chrysanthemun and tobacco morphogenesis and Agrobacterium growth. J Appl. Hort. 3(I): 3-12.

De Baar, H.J.W. \& La Roche, J. 2003. Metals in the Oceans; Evolution, Biology and Global Change. Springer Verlag. Berlin (DE), p. 79105.

[FAO] Food and Agriculture Organization. 2010. FAOSTAT database. [online]. http:/ faostat.fao.org.

Handayani, T. 2013. Konstruksi vektor biner dan transformasi gen lisozim pada rumput laut Kappaphycus alvarezii menggunakan perantara Agrobacterium tumefaciens. Seminar hasil sekolah pasca sarjana. Bogor(ID). Institut Pertanian Bogor.

Hiei, Y. \& Komari, T. 2008. Agrobacterium-mediated transformation of rice using immature embryos or calli induced from mature seed. Nature Protocol, 3(5): 824-826.

Jickells, T. 1995. Atmospheric inputs of metals and nutrients to the oceans: their magnitude and effects. Marine Chem., 48(3-4): 199-214.

Joubert, Y. \& Fleurence, J. 2005. DNA isolation protocol for seaweeds. Plant Mol Biol Rep., 23: 197a-197g.

Koronfel, M. 1998. Effects of the antibiotics kanamycin, cefotaxime, and carbenicillin on the differentiation of flax hypocotyls. Arab J. Biotechnol., 1(1): 93-98.

Largo, D.B., Faukami, K., Adachi, M., \& Nhisijima, T. 1997. Direct enumeration of total bacte- ria from macroalgae by epifluoresecence microscopy asapllied to the flashy red algae Kappaphycus alvarezii and Glacilaria Spp (Rhodophyta), J. Phycol., 33: 554-557.

Mtolera, M.S.P., Collén, J., Pedersen, M., \& Semesi, A.K. 1995. Destructive hydrogen peroxide production in Eucheuma denticulatum (Rhodophyta) during stress caused by elevated ph, high light intensities and competition with other species. Eur J Phycol., 30: 289-297.

Nagy, N.E., Dalen, L.R., Jones, D.L., Swensen, B., Fossdal, C.G., \& Eldhuset, T.D. 2004. Cytologycal an enzymatic responses to aluminum stress in root tips of norway spruce seedlings. New Phytol., 163(3): 595607.

Okkels, F.T. \& Padersen, M.G. 1988. The toxicity to plant tissue and to agrobacterium tumefaciens of some antibiotic. Acta Hort, 255: 199-207.

Suryati, E. \& Mulyaningrum, S.R.H. 2009. Regenerasi rumput laut Kappaphycus alvarezii (Doty) melalui induksi kalus dan embrio dengan penambahan hormon perangsang tumbuh secara In vitro. J. Ris. Akuakultur, 4(1): 39-45.

Taiz, L. \& Zeiger. 2002. Plant Physiolgy. 3th edition. Sinauier Associated Inc. Publishers. Sunderland Massachusetts, $637 \mathrm{pp}$.

Tistama, R. 2012. Isolasi dan introduksi gen Sitrat Sintase dari Pseudomonas aeruginosa ke dalam tanaman untuk meningkatkan toleransi terhadap cekaman aluminium [Disertasi]. Bogor (ID): Institut Pertanian Bogor.

Vairappan, C.S. 2006. Seasonal accurrecences of epiphytic algae on the comercially cultivated red algae Kappaphycus alvarezii (Soliriciae, Gigartinales, Rhodophyta). J. Appl. Phycol., 18: 611-617.

Yamamoto, Y., Kobayashi, Y., \& Matsumoto, H. 2001 . Lipid peroxidation is an early symptom triggered by aluminum, but not the primary cause of elongation inhibition in pea roots. Plant Physiol., 125: 199-208. 